\title{
PRODUKSI INOKULUM MIKORIZA ARBUSKULA DARI KEDALAMAN GAMBUT BERBEDA YANG DIBERI CUKA ORGANIK DENGAN INANG JAGUNG (Zea mays L.)
}

\author{
Production of Arbuscular Mycorrhizal Inoculums From Defferent Peat Depths Given Organic \\ Vinegar With Maize Host (Zea mays L.)
}

\author{
Siti Indriani, Hanna Artuti Ekamawanti, Burhanuddin \\ Fakultas Kehutanan Universitas Tanjungpura, Jalan Imam Bonjol Pontianak, 78124 \\ Email: sitindriani20@gmail.com
}

\begin{abstract}
The aim of this study was to obtain organic vinegar suitable for the production of arbuscular mycorrhizal inoculums from the initial inoculum at different peat depths. The long-term goal is to obtain an alternative use of organic vinegar-based stimulants from rubber wood waste, fern roots and peat for the production of arbuscular mycorrhizal inoculums from peat soil. This study used an experimental method using a divided plot design (RPT) with a basic pattern of $R A K$. The first factor placed in the main plot is the depth of peat while the second factor is placed in subplots, namely organic vinegar. The number of FMA spores and FMA colonization of the roots was observed after breeding. The results showed that fertilization treatment had an effect on the production of inoculum, while the depth of extraction of peat soil had no effect in the production of arbuscular mycorrhizal inoculums. The average number of spores in each treatment was fertilizating commercial NPK fertilizers 2.788,33 spores, fertilizing rubber wood vinegar 2.194,67 spores, fertilizing fern root vinegar in 1934 spoes, fertilizing 1418 spores peat vinegar and without fertilizing 1.292 spores. Average percentage of root colonization produced was NPK commercial fertilizerz 71,67\% (high), rubber wood vinegar $81,67 \%$ (very high), fern root vinegar $76,67 \%$ (very high), 50\% (medium) peat vinegar and no fertilization $73,33 \%$ (high). Based on the analysis of rubber wood vinegar data, fern root vinegar and peat vinegar produced an average number of spores that were not significant compared to commercial NPK fertilizers, so that the three types of organic vinegar had the potential to stimulate arbuscular mycorrhizal inoculums in the form of spores and root colonization.
\end{abstract}

Keywords: Arbuscular mycorrhizal inoculum, maize, organic vinegar, peat depth

\section{PENDAHULUAN}

Masyarakat terkadang masih menerapkan teknik pembakaran dalam penyiapan lahan gambut untuk kepentingan budidaya tanaman. Pembakaran lahan gambut dapat berakibat pada kerusakan lahan gambut hingga menjadi lahan kritis. Berbagai upaya perbaikan tanah gambut berupa konservasi tanah dan air secara fisik, kimia, dan biologi telah banyak dilakukan. Sebagai upaya dari usaha-usaha konservasi yang dapat dilakukan adalah penggunaan agens hayati. Pemanfaatan fungi mikoriza arbuskula sebagai agens hayati diyakini mampu memperbaiki kondisi tanah dan yang paling utama meningkatkan penyerapan unsur hara tanaman. Fungi mikoriza arbuskula dapat dijadikan sebagai salah satu alternatif untuk membantu pertumbuhan, meningkatkan produktivitas dan kualitas tanaman terutama yang ditanam pada lahan-lahan 
marginal yang kurang subur atau bekas tambang/industri (Smith dan Read 1997).

Penggunaan fungi mikoriza arbuskula (FMA) dalam perbaikan tanah diperlukan ketersediaaan inokulum mikoriza arbuskula yang unggul terutama dari jenis lokal atau asli. Penggunaan inokulum yang baik atau sesuai merupakan sangat penting untuk mencapai keberhasilan perbaikan tanah. Dalam hal ini diperlukan untuk ketersediaan inokulum dalam jumlah besar mengingat untuk luasan suatu kawasan yang akan diperbaiki juga besar. Penyediaan inokulum mikoriza arbuskula dalam jumlah besar selalu menjadi kendala utama dalam pemanfaatan FMA sebagai agens hayati di lapangan. Salah satu cara perbanyakan FMA yang banyak dilakukan adalah dengan menggunakan kultur pot (Suhardi 1989). Metode kultur pot yaitu inokulum awal FMA diinokulasikan pada tanaman inang tertentu pada medium padat yang steril (Simanungkalit 2003). Istilah kultur pot biasanya juga dikenal dengan istilah penangkaran.

Faktor yang mempengaruhi keberhasilan penangkaran FMA yaitu sumber inokulum awal (kedalaman pengambilan tanah) dan stimulan sporulasi. Kedalaman gambut mempengaruhi keberadaan spora FMA di dalam tanah. Kelimpahan spora di tanah gambut semakin meningkat sampai kedalaman $60 \mathrm{~cm}$ dan berkurang serta semakin sedikit pada kedalaman $100 \mathrm{~cm}$ (Hermawan et al. 2015). Selain itu, pemberian nutrisi terhadap tanaman dalam penangkaran juga akan berpengaruh pada sporulasi FMA. Pemupukan $\mathrm{P}$ dengan takaran dan kelarutan tinggi dilaporkan dapat menurunkan daya kolonisasi dan efektivitas propagul FMA (Bhadalung et al. 2005).

Seiring dengan berkembangnya ilmu pengetahuan dan teknologi, perlu dilakukan suatu pendekatan berupa stimulasi FMA dengan tujuan untuk meningkatkan produksi inokulum mikoriza arbuskula. Beberapa penelitian dalam inokulasi spora yang digunakan yaitu menggunakan pupuk kimia dengan kandungan $\mathrm{P}$ yang rendah. Ketersedian unsur fosfor yang rendah pada media maka perkembangan spora juga meningkat. Salah satu alternatif yang dapat digunakan untuk meningkatkan produksi inokulum mikoriza adalah cuka organik. Cuka organik yang digunakan yaitu berupa cuka kayu karet, cuka gambut, dan cuka akar pakis. Pemanfaatan cuka kayu umumnya di sektor pertanian antara lain dapat membuat tanaman menjadi sehat juga membantu mengendalikan hama dan penyakit tanaman (Satriadi et al. 2010). Bahan-bahan tertentu dalam cuka kayu dapat meningkatkan aktivitas dan konsentrasi mikroorganisme tanah (Sadakichi et al. 2009). Cuka gambut dan cuka akar pakis merupakan komoditas yang relatif baru, sehingga masyarakat belum banyak mengenalnya. Manfaat yang dihasilkan dari cuka gambut dan cuka akar pakis diduga memiliki manfaat yang sama dengan cuka kayu yaitu dapat membantu pertumbuhan tanaman serta mengendalikan hama dan penyakit (Rustamaji, komunikasi pribadi 2018).

Mengetahui dari keberadaan spora di tanah gambut serta manfaat yang terdapat 
pada cuka organik, maka masalah yang terdapat pada penelitian ini yaitu: 1). Hasil penelitian terdahulu menunjukkan bahwa kedalaman gambut berpengaruh pada kelimpahan spora FMA. Namun perlu diuji apakah di lokasi pengambilan sumber awal inokulum FMA di Kuala Dua kecamatan Sungai Raya kabupaten Kubu Raya juga berpengaruh yang sama. 2). Penggunaan cuka organik (cuka kayu, cuka gambut dan cuka akar pakis) sebagai stimulan untuk sporulasi FMA dalam produksi inokulum belum diketahui pengaruhnya.

Tujuan penelitian ini yaitu mendapatkan cuka organik yang sesuai untuk produksi inokulum mikoriza arbuskula dari inokulum awal pada kedalaman gambut berbeda. Manfaat dari penelitian ini diharapkan dapat memberikan kontribusi pada pengembangan ilmu pengetahuan dan teknologi hayati khususnya pada pengembangan produksi inokulum FMA yang distimulasi dengan cuka organik.

\section{METODOLOGI}

Tempat pengambilan sampel di desa Kuala Dua kecamatan Sungai Raya kabupaten Kubu Raya, dilanjutkan dengan penangkaran spora dengan inang jagung di Rumah Kasa Universitas Tanjungpura dan selanjutnya pengamatan spora di Laboratorium Silvikultur Fakultas Kehutanan Universitas Tanjungpura Pontianak. Lamanya penelitian berlangsung selama \pm 5 bulan. Alat dan bahan yang digunakan dalam penelitian adalah penggaris dengan panjang $100 \mathrm{~cm}$, sekop kecil, kantong plastik, kertas label, nampan, hand sprayer, pot kultur (160
$\mathrm{mL}$ ), cawan Petri, gelas Beaker, gelas ukur, batang pengaduk, timbangan analitik, satu set saringan $(0,21 \mathrm{~mm}, 125$ $\mu \mathrm{m}, 63 \mu \mathrm{m}$, dan $45 \mu \mathrm{m})$, mikroskop stereo, mikroskop slide, pipet plastik, jarum suntik, pinset, kertas saring, kamera. pisau, Termometer udara, higrometer, Tally sheet, sampel tanah gambut, $\mathrm{NaOCl}$ $5,25 \%$, pasir sungai, Aquades, pupuk komersil dengan kandungan NPK (25-520), cuka kayu karet, cuka akar pakis, cuka gambut, polyviny lactol glycerol (PVLG), Larutan Melzer, $\mathrm{KOH}$ 10\%, cuka makan 5\%, tinta Quink, gliserol teknis.

\section{Prosedur Penelitian}

1. Pengambilan sampel tanah gambut

Contoh tanah diambil pada kawasan gambut dengan pengambilan masingmasing $200 \mathrm{~g}$ yang ditentukan berdasarkan jarak dari parit dan kedalam pengambilan tanah. Jarak dari parit yang digunakan yaitu $20 \mathrm{~m}, 50 \mathrm{~m}$, dan $80 \mathrm{~m}$ sedangkan untuk kedalam pengambilan sampel gambut yaitu $0-50 \mathrm{~cm}$ dan $50-100 \mathrm{~cm}$. Pengambilan sampel gambut dilakukan pada 3 jalur sehingga total sampel yang diambil sebanyak 18 sampel tanah. Sampel gambut yang sudah diambil lalu dicampur atau dikompositkan berdasarkan jarak pengambilan dan kedalaman pengambilan sampel gambut yang sama dari ketiga jalur tersebut, sehingga sampel gambut menjadi 6 sampel. Setelah tercampur sampel gambut dimasukkan ke dalam kantong plastik dan diberi label. Pengukuran kondisi tanah seperti suhu dan kelembapan juga dilakukan pada waktu pengambilan sampel gambut.

2. Persiapan media pengecambahan benih 
Media yang digunakan untuk media perkecambahan adalah pasir sungai yang dicuci bersih kemudian disterilisasi dengan oven selama 24 jam. Benih jagung yang akan digunakan sebagai tanaman inang disterilisasi dengan $\mathrm{NaOCl}$ 5,25\% selaman 20 detik kemudian bilas dengan air sampai bersih. Selanjutnya benih direndam dalam air hangat $\left(70^{\circ} \mathrm{C}\right)$ selama 15 menit. Bak perkecambahan diisi dengan pasir steril. Selanjutnya penaburan benih tanaman inang ke dalam nampan perkecambahan yang telah terisi pasir kemudian ditutup dengan pasir. Selama perkecambahan dijaga kelembapan media dengan memberikan air bersih pada bak perkecambahan yang tidak dilubangi dan ditempatkan berlapis di bagian bawah bak perkecambahan benih. Benih yang telah berkecambah dipindahkan ke pot-pot kultur yang telah diisi dengan pasir sungai dan inokulum FMA.

3. Inokulasi inang dengan inokulum FMA

Metode inokulasi yang digunakan mengacu pada Brundrett et al. (1996) yaitu: Masing-masing pot kultur diisi dengan pasir sungai sebanyak $1 / 4$ volume pot, kemudian inokulum diletakkan di atasnya ( $1 / 2$ volume pot), lalu dilapisi dengan pasir sungai lagi sebanyak $1 / 4$ volume pot, setelah itu kecambah diletakkan dalam lubang yang telah dibuat pada permukaan media perbayakan. Setelah tanaman berumur 1 minggu dari penanaman ke dalam pot, tanaman dipindah ke rumah kasa Universitas Tanjungpura untuk pemeliharaan selanjutnya.
4. Pemeliharaan dan pemberian perlakuan

Pemeliharaan dilakukan dengan pemberian air kapasitas lapang yaitu air yang dapat ditahan oleh tanah setelah air gravitasi turun. Penyiraman dilakukan pada pagi jam 06.00-08.00 dan sore pada jam 16.00-18.00. Satu minggu setelah pemindahan dari laboratorium Silvikultur Universitas Tanjungpura tempat penyemaian dilakukan pemupukan cuka kayu karet, cuka gambut, cuka akar pakis, pupuk komersil kandungan NPK (25-520) dan tanpa perlakuan. Dosis pupuk komersil kandungan NPK (25-5-20) yang digunakan yaitu $1 \mathrm{~g} / \mathrm{L}$ air, sedangkan untuk pengenceran cuka organik yaitu 4 $\mathrm{mL} / \mathrm{L}$ air. Pemupukan dilakukan pada hari Senin dan Kamis dengan waktu pemupukan pagi jam 06.00-08.00 dan sore jam 16.00-18.00 dengan pemupukan sebanyak $20 \mathrm{~mL}$ pot. Pada minggu ke 1214 (selama 2 minggu) tanaman dilakukan stress hara dan air untuk merangsang sporulasi.

5. Pemanenan

Pemanenan dilakukan pada minggu ke 14 setelah inokulasi. Pemanenan dilakukan dengan mengeluarkan media tanaman dari pot secara hati-hati. Bagian atas tanaman pada bagian leher akar dipotong dengan gunting tajam kemudian media tersebut dimasukkan ke dalam kantong plastik transparan.

6. Pengamatan infeksi akar

Sampel akar yang telah dihasilkan dibawa ke laboratorium dan dilakukan pengamatan dengan cara pewarnaan akar dan pembuatan preparat sampel akar. 
7. Ekstraksi spora fungi mikoriza arbuskula (FMA)

Isolasi spora FMA dilakukan dengan teknik penyaringan basah (Brundrett et al. 1994) dengan cara sebagai berikut: seluruh media tumbuh $130 \mathrm{~g} /$ pot disuspensikan dalam $300 \mathrm{~mL}$ air, kemudian diaduk rata hingga butiran-butiran tanah hancur, suspensi tanah dituangkan ke penyaring bertingkat $(0,21 \mathrm{~mm}, 125 \mu \mathrm{m}, 63 \mu \mathrm{m}, 45$ $\mu \mathrm{m})$, endapan yang ada pada penyaring 63 $\mu \mathrm{m}$ dan $45 \mu \mathrm{m}$, dipindahkan ke cawan Petri, selanjutnya diperiksa di bawah mikroskop stereo.

8. Karakterisasi tipe spora FMA

Karakterisasi dilakukan untuk menentukan jenis FMA. Adapun langkah karakterisasi spora FMA yaitu spora diambil dengan pinset spora atau pipet plastik dari hasil isolasi (ekstraksi), spora yang telah diambil diletakkan di atas kaca objek sebanyak dua spora dengan penempatan pada kiri dan kanan kaca objek, spora yang terdapat pada kiri kaca objek diberi PVLG sedangkan spora pada kanan kaca objek diberi PVLG+Melzer, Selanjutnya spora ditutup dengan cover slip dan dilakukan pengamatan. Jenis spora yang diamati adalah bentuk spora, warna spora, dan lekatan tangkai hifa dari spora FMA serta tekstur spora dengan menggunakan buku Manual for the Identification of VA Mycorrhizal Fungi (Schenck dan Perez 1990) sebagai acuan untuk karakterisasi spora.

9. Menghitung jumlah spora fungi mikoriza arbuskula (FMA)

Jumlah spora FMA dihitung berdasarkan spora yang ditemukan dalam sampel tanah melalui proses penyaringan basah dengan. Perhitungan jumlah spora FMA dilakukan dengan metode garis grid.

\section{Rancangan Percobaan}

Penelitian ini menggunakan metode eksperimen dengan menggunakan rancangan petak terbagi (RPT) dengan pola dasar RAK. Faktor yang ditempatkan dalam petak utama yaitu kedalaman gambut (D) terdiri dari 2 taraf faktor D1= 0 $-50 \mathrm{~cm}, \mathrm{D} 2=50-100 \mathrm{~cm}$. Faktor kedua yang ditempatkan dalam anak petak yaitu perlakuan pemupukan $(\mathrm{P})$ terdiri dari 5 taraf faktor $\mathrm{P} 0=$ Tanpa pemupukan, $\mathrm{P} 1=$ Pupuk komersil kandungan NPK (25-525), $\mathrm{P} 2=$ Cuka kayu karet, $\mathrm{P} 3$ = Cuka gambut, $\mathrm{P} 4=$ Cuka akar pakis. Pengelompokan didasarkan pada pengambilan gambut dari parit yaitu $20 \mathrm{~m}$, $50 \mathrm{~m}$, dan $80 \mathrm{~m}$. Total jumlah tanaman adalah 3 (kelompok) x 2 (faktor pertama) x 5 (faktor kedua) $=30$ tanaman .

\section{Pengumpulan Data}

Data pokok dalam penelitian ini adalah persentase akar yang terinfeksi FMA serta kepadatan spora dan jenis spora FMA. Data penunjang berupa hasil pengukuran suhu udara, kelembaban udara, dan suhu tanah di lokasi pengambilan sampel tanah serta hasil pengukuran suhu udara dan kelembapan udara di Rumah Kasa Universitas Tanjungpura tempat penangkaran.

HASIL DAN PEMBAHASAN

\section{Produksi Inokulum Mikoriza}

Arbuskula Berdasarkan Jumlah Spora dan Kolonisasi Akar

Hasil analisis keragaman faktor pemupukan berpengaruh nyata pada produksi spora FMA selama 14 minggu setelah inokulasi, sedangkan untuk faktor 
kedalaman dan interaksi faktor kedalaman dengan faktor pemupukan berpengaruh tidak nyata. Data hasil analisis keragaman dapat dilihat pada Tabel 1 .

Tabel 1. Analisis keragaman jumlah spora FMA dari kedalaman gambut berbeda yang diberi cuka organik (Analisis of the diversity of FMA spore numbers from different peat depths given organic vinegar)

\begin{tabular}{lcc}
\hline & Sumber Keragaman & Jumlah Spora \\
\hline & Kedalaman (D) & $11,37^{\text {th }}$ \\
& Pemupukan (P) & $3,62^{*}$ \\
& Interaksi (DP) & $1,84^{\text {tn }}$ \\
\hline Keterangan : & $*$ = Berbeda nyata pada $\alpha=0,05$ & \\
& tn $=$ Berbeda tidak nyata pada $\alpha=0,05$ &
\end{tabular}

Hasil analisis keragaman pada Tabel 1 menunjukkan bahwa faktor kedalaman dan interaksi faktor kedalaman dengan faktor pemupukan berpengaruh tidak nyata. Jumlah spora pada kedalaman 0-50 cm menunjukkan bahwa jumlah spora lebih sedikit dibandingkan pengambilan gambut kedalaman 50-100 cm namun perbedaan tersebut tidak signifikan. Sumber inokulum awal yang digunakan untuk produksi spora bisa dari kedalaman 0$50 \mathrm{~cm}$ dan 50-100 cm. Jumlah spora yang dihasilkan pada kedalaman 0-50 $\mathrm{cm}$ dan 50-100 $\mathrm{cm}$ diduga terjadi karena sifat fisik dan sifat kimia tanah gambut di kedalaman keduanya tidak ada perbedaan sehingga sporulasi yang dihasilkan pada kedalaman 0-50 cm dan adalah tanah yang terbentuk dari timbunan sisa-sisa tanaman yang telah mati, baik yang sudah lapuk maupun belum. Material organik tersebut terus menumpuk dalam waktu lama sehingga membentuk lapisan-lapisan dengan ketebalan lebih dari $50 \mathrm{~cm}$ atau lebih. Ketebalan tanah gambut bahkan lebih dari $300 \mathrm{~cm}$ (Hardjowigeno dan Abdullah 1987).

Faktor pemupukan berpengaruh nyata pada produksi spora FMA selama 14 minggu setelah inokulasi. Selanjutnya untuk mengetahui taraf faktor pemupukan yang menunjukkan perbedaan rerata jumlah spora FMA, maka dilakukan uji beda nyata terkecil (BNT). Hasil perhitungan uji BNT dapat dilihat pada Tabel 2. 50-100 cm tidak berbeda. Gambut

Tabel 2. Rerata jumlah spora hasil penangkaran dengan inang jagung yang diberi cuka organik (The average number of FMA spores from captive breeding with maize host given organic vinegar)

\begin{tabular}{cc}
\hline Pemupukan & Rerata Jumlah Spora / $135 \mathrm{~g}$ \\
\hline Pupuk Komersil NPK & $2788,33 \mathrm{a}$ \\
Cuka Kayu Karet & $2194,67 \mathrm{ab}$ \\
Cuka Akar Pakis & $1934,00 \mathrm{ab}$ \\
Cuka Gambut & $1418,00 \mathrm{~b}$ \\
Tanpa Pemupukan & $1292,00 \mathrm{~b}$ \\
\hline
\end{tabular}

Keterangan : Angka yang diikuti oleh huruf yang tidak sama adalah berbeda nyata dengan uji BNT pada taraf $\alpha=0,05$ 
Hasil uji BNT pada Tabel 2 menunjukkan bahwa rerata jumlah spora FMA yang dihasilkan pada perlakuan pemupukan pupuk komersil NPK paling banyak dan berbeda nyata dibandingkan dengan perlakuan cuka gambut dan tanpa pemupukan. Pupuk komersil NPK menghasilkan rerata jumlah spora yang tidak signifikan dengan cuka kayu karet dan cuka akar pakis. Rerata jumlah spora yang dihasilkan pada pemupukan cuka kayu karet dan cuka akar pakis tidak berbeda dengan perlakuan pemupukan pupuk komersil NPK, cuka gambut dan tanpa pemupukan. Perlakuan pemupukan cuka kayu karet menghasilkan jumlah spora paling banyak diantara cuka organik yaitu cuka gambut dan cuka akar pakis namun perbedaan tersebut tidak signifikan.

Produk inokulum mikoriza arbuskula yang dihasilkan dari keempat perlakuan pemupukan tersebut diduga telah dipengaruhi oleh kandungan senyawa organik serta komposisi dari bahan perlakuan pemupukan. Pupuk komersil NPK diketahui memiliki kandungan unsur $\mathrm{P}$ yang rendah $(5 \%)$ sehingga dapat memberikan pengaruh yang baik terhadap produksi spora FMA. Diketahui dari analisis cuka akar pakis $(6 \%)$ dan cuka gambut $(8 \%)$ mengandung unsur $\mathrm{P}$ lebih besar dibanding pupuk komersil NPK sehingga diduga dapat mempengaruhi sporulasi FMA. Cuka kayu karet memiliki kandungan unsur $\mathrm{P}$ lebih rendah $(1,2 \%)$ dari pupuk komersil NPK sehingga jumlah spora FMA yang dihasilkan tidak signifikan dengan jumlah spora FMA perlakuan pupuk komersil NPK. Semakin tinggi takaran pemupukan NPK maka kolonisasi dan sporulasi FMA semakin menurun (Husna et al. 2017).

Perkembangan FMA dapat terhambat dengan adanya pemupukan $\mathrm{P}$ dengan konsentrasi tinggi karena secara tidak langsung mempengaruhi karbohidrat yang dihasilkan dari proses fotosintesis dimana karbohidrat yang dihasilkan juga merupakan salah satu energi bagi FMA namun apabila tidak sesuai dengan karakteristik isolat FMA diberikan maka dapat menghambat sporulasi FMA (Delvian 2006). Perbedaan sensitifitas terhadap pemupukan diduga merupakan akibat dari perbedaan terhadap kebutuhan karbohidrat terlarut dari eksudat akar (Douds dan Schenck 1990). Eksudat akar diproduksi lebih banyak pada perlakuan dengan takaran fosfor rendah (Gunawan 1993). Selain itu cuka organik juga mengandung fenol. Penggunaan fenol dalam konsentrasi yang besar diketahui dapat menurunkan aktifitas mikroba tanah diantaranya spora FMA (Sadakichi et al. 2009).

Produk inokulum mikoriza arbuskula tidak hanya berupa spora melainkan juga berupa kolonisasi akar. Penentuan kolonisasi akar yaitu berdasarkan banyaknya hifa FMA yang menginfeksi akar maupun ada tidaknya spora yang terdapat dalam lapisan akar (korteks), sehingga apabila terdapat hifa atau spora FMA yang menginfeksi akar maka akan didapatkan tingkat 
persentase infeksi akar baik itu sangat tinggi, tinggi, sedang, rendah maupun sangat rendah. Persentase rerata infeksi akar oleh FMA dari 5 perlakuan dapat dilihat pada Tabel 3.

Tabel 3. Rerata persentase akar terinfeksi FMA pada tanaman jagung yang telah dilakukan penangkaran (The average percentage of roots infected with FMA in maize plants that have been carried out captivity)

\begin{tabular}{ccc}
\hline Perlakuan & Persentase infeksi akar & Keterangan \\
\hline Tanpa perlakuan & 73,33 & Tinggi \\
Pupuk komersil NPK & 71,67 & Tinggi \\
Cuka kayu karet & 81,67 & Sangat tinggi \\
Cuka gambut & 50 & Sedang \\
Cuka akar pakis & 76,67 & Sangat tinggi \\
\hline
\end{tabular}

Perlakuan pupuk komersil NPK menghasilkan infeksi akar lebih rendah dibandingkan perlakuan cuka kayu karet dan cuka akar pakis. Perlakuan pupuk komersil NPK menghasilkan kolonisasi sama dengan perlakuan tanpa pemupukan. Kolonisasi paling rendah dihasilkan pada perlakuan pemupukan cuka gambut. Hal ini berbeda dalam produksi spora (sporulasi) FMA dimana perlakuan pupuk komersil NPK lebih tinggi dibandingkan perlakuan cuka kayu karet dan cuka akar pakis, sedangkan pada kolonisasi FMA pada perlakuan cuka kayu karet dan cuka akar pakis didapatkan hasil yang lebih tinggi dibandingkan perlakuan pupuk komersil NPK. Penelitian ini menunjukkan bahwa cuka kayu karet dan cuka akar pakis dapat menciptakan kondisi yang baik untuk proses kolonisasi pada akar.
Kolonisasi FMA dari infeksi akar tidak selalu berkolerasi positif dengan produksi spora FMA, karena proses tersebut dipengaruhi beberapa faktor yaitu kondisi inokulum, lama waktu inkubasi, lingkungan, jenis inang dan juga tempat tumbuh (Muaz 2003; Chalimah et al. 2007). Populasi spora tidak selalu sama dengan kolonisasi FMA terhadap akar karena akan berbeda untuk setiap jenis FMA, jenis tanaman dan tergantung pada variabel lingkungan (Smith dan Read 2008). Ketersediaan nitrogen, fosfat dan kalium akan mengurangi kolonisasi akar bila terdapat di dalam tingkat ketersediaan yang tinggi (Smith dan Read 2008).

Berikut ini adalah gambar hasil pengamatan infeksi akar yang tampak adanya interaksi antara FMA dengan akar tanaman. 


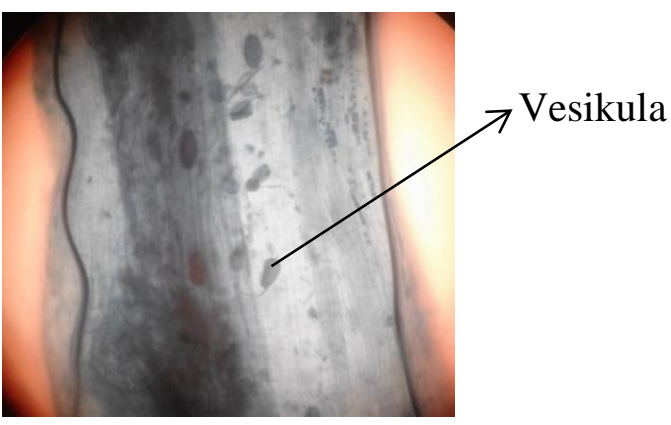

(a)

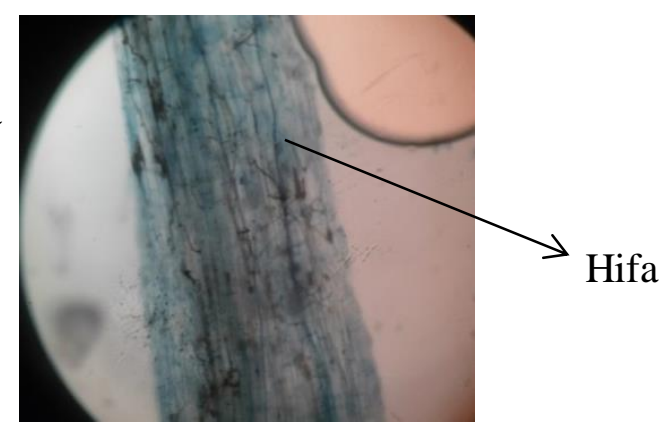

(b)

Gambar 1. Struktur FMA di dalam akar (a) Vesikula, (b) Hifa, dengan perbesaran $40 \times$ (FMA structure inside the root (a) Vesicles (b) hyphae, with $40 x$ magnification)

Data sekunder merupakan data yang diambil di lapangan pada lokasi pengambilan sampel inokulum awal mikoriza arbuskula dan di rumah kasa tempat penangkaran berupa data $\mathrm{pH}$ tanah, suhu udara, kelembapan udara dan suhu tanah. Rerata data sekunder pada lokasi pengambilan sampel yaitu $\mathrm{pH}$ tanah berkisar 3,5, suhu tanah 29,3 ${ }^{\circ} \mathrm{C}$, suhu udara $28,1{ }^{\circ} \mathrm{C}$ dan kelembapan udara dengan rerata $56,4 \%$. Rerata data sekunder di Rumah Kasa yaitu suhu udara $29,2{ }^{\circ} \mathrm{C}$ dan kelembapan udara $66,6 \%$.

Berdasarkan data sekunder yang telah diambil dari lokasi pengambilan sampel tanah dan lokasi saat dilakukan penangkaran kondisi lingkungan termasuk sesuai untuk pertumbuhan dan perkembangan FMA. Hal ini sesuai dengan jumlah spora serta infeksi FMA dengan akar yang telah dihasilkan dari penangkaran. Schenk dan Schroder (1974) menyatakan bahwa suhu terbaik untuk perkembangan arbuskula yakni pada suhu $30^{\circ} \mathrm{C}$, tetapi untuk kolonisasi miselia yang terbaik adalah pada suhu $28^{\circ} \mathrm{C}-35^{\circ} \mathrm{C}$. Perkembangan FMA pada lahan gambut yang terbaik yaitu pada kisaran suhu $27^{\circ} \mathrm{C}-30^{\circ} \mathrm{C}$ (Muin 2007).

Produk inokulum dari keduanya memiliki sifat yang berbeda dalam waktu penyimpanannya. Produk inokulum berupa spora dapat bertahan di dalam tanah tanpa tanaman inang sampai 6 bulan, beberapa spesies seperti Scutelospora dan Gigaspora dapat bertahan satu sampai dua tahun (Brundrett 2004). Namun, produk inokulum berupa kolonisasi akar berbeda dengan produk berupa spora yaitu tidak bisa disimpan dalam waktu yang lama dan harus segera digunakan.

Jenis spora ditentukan berdasarkan tipe spora yang meliputi bentuk spora, warna spora, dinding spora, letakan tangkai spora hifa, dan tekstur permukaan spora FMA. Berdasarkan karakterisasi tersebut ditemukan 5 jenis spora FMA yang termasuk genus Glomus. Jumlah spora dapat dilihat pada Tabel 4. 
Tabel 4. Jumlah spora berdasarkan jenis FMA dari setiap perlakuan setelah dilakukan penangkaran (The number of spores based on the type of FMA from each treatment after captivity)

\begin{tabular}{ccccccc}
\hline \multirow{2}{*}{$\begin{array}{c}\text { Kedalaman } \\
\text { Gambut }\end{array}$} & Tipe FMA & \multicolumn{5}{c}{ Pemupukan } \\
\cline { 3 - 7 } & Glomus sp. 1 & 1938 & 3889 & 2431 & 3310 & 3009 \\
& Glomus sp. 2 & 496 & 1065 & 550 & 666 & 498 \\
D1 & Glomus sp. 3 & 959 & 1456 & 1495 & 1217 & 931 \\
& Glomus sp. 4 & 196 & 303 & 123 & 180 & 124 \\
& Glomus sp. 5 & 386 & 218 & 436 & 437 & 292 \\
\hline Jumlah & & 3975 & 6931 & 5035 & 5810 & 4854 \\
\hline \multirow{2}{*}{ D2 } & Glomus sp. 1 & 1709 & 5468 & 4154 & 1427 & 3533 \\
& Glomus sp. 2 & 651 & 1080 & 1221 & 243 & 863 \\
& Glomus sp. 3 & 885 & 2139 & 1884 & 642 & 1475 \\
& Glomus sp. 4 & 224 & 389 & 298 & 140 & 273 \\
& Glomus sp. 5 & 308 & 723 & 576 & 246 & 606 \\
\hline Jumlah & & 3777 & 9799 & 8133 & 2698 & 6750 \\
\hline
\end{tabular}

Dilihat dari hasil penelitian pada Tabel 4 bahwa terdapat 5 jenis FMA yaitu Glomus sp. 1, Glomus sp. 2, Glomus sp. 3, Glomus sp. 4, Glomus sp. 5. Jenis FMA yang memiliki jumlah spora paling banyak yaitu Glomus sp. 1 sedangkan jenis FMA yang memiliki jumlah paling sedikit yaitu Glomus sp. 4. Genus Glomus mempunyai tingkat adaptasi yang tinggi terhadap lingkungan tanah yang masam (Sasli 2012). Kelimpahan jenis spora pada lahan gambut dengan beda kedalaman muka air gambut didominasi oleh genus Glomus (Hermawan et al. 2015).

\section{Potensi Cuka Organik Untuk} Produksi Inokulum Mikoriza Arbuskula

Berdasarkan analisis data yang telah dilakukan bahwa penggunaan cuka organik sebagai stimulan untuk produksi inokulum mikoriza arbuskula memberikan pengaruh yang cukup baik dan berpotensi sebagai stimulan untuk produksi inokulum mikoriza arbuskula. Cuka organik yang memiliki potensi dalam produksi inokulum mikoriza arbuskula yaitu cuka kayu karet, cuka akar pakis dan cuka gambut. Tiga jenis cuka organik telah menghasilkan rerata jumlah spora yang tidak signifikan, namun jumlah spora yang dihasilkan memiliki jumlah yang berbeda pada setiap perlakuan cuka organik.

Cuka kayu karet menghasilkan jumlah spora paling banyak dan menghasilkan kolonisasi sangat tinggi sehingga cuka kayu karet berpotensi yang paling baik sebagai stimulan dalam produksi inokulum mikoriza arbuskula. Cuka akar pakis menghasilkan jumlah spora lebih sedikit dari cuka kayu karet dan kolonisasi yang dihasilkan yaitu termasuk dalam kategori sangat tinggi. Cuka gambut menghasilkan jumlah spora paling sedikit diantara cuka organik dan menghasilkan kolonisasi akar termasuk 
dalam kategori sedang. Produk inokulum mikoriza arbuskula yang telah di hasilkan belum diketahui keefektifannya terhadap pertumbuhan tanaman. Perlu dilakukan penelitian selanjutnya guna mengetahui keefektifan dari produk inokulum mikoriza arbuskula yang dihasilkan dari penggunaan stimulan cuka organik terhadap pertumbuhan tanaman.

Penggunaan cuka organik sebagai pemupukan dalam pengaplikasiannya terhadap tanaman juga perlu dilakukan penelitian sehingga dapat diketahui pengaruh cuka organik sebagai faktor pemupukan terhadap perkembangan FMA yang diinokulasikan terhadap tanaman serta pertumbuhan tanaman. Menurut Departemen Pertanian Thailand (2010) cuka kayu memiliki manfaat sebagai peningkatan kualitas tanah, menghilangkan hama, mampu mempercepat perkembangan akar, batang umbi, daun, bunga dan buah. Hasil penelitian lain menyebutkan bahwa cuka kayu dapat meningkatkan kualitas tanah, menghilangkan hama, mempercepat pertumbuhan tanaman dan sebagai zat pengatur tumbuh (Apai dan Thongdeethae 2001). Jika cuka kayu diterapkan ke tanah dalam konsentrasi tinggi dapat menghambat cacing dan penyakit pada tanah, sedangkan dalam konsentrasi rendah dapat meningkatkan jumlah mikroba yang berguna (Sadakichi et al. 2009). Hasil penelitian lain menyebutkan cuka kayu dengan konsentrasi $2 \%$ dapat meningkatkan pertumbuhan tanaman (Komarayati dan Susanto 2011).

\section{KESIMPULAN}

1. Perbanyakan spora pada inokulum awal FMA yang berasal dari tanah gambut di Kuala Dua kecamatan Sungai Raya kabupaten Kubu Raya pada kedalaman berbeda memberikan pengaruh yang tidak nyata, sehingga sumber inokulum kedalaman 0-50 cm dan 50-100 cm bisa digunakan dalam produksi inokulum mikoriza arbuskula.

2. Cuka organik yang sesuai dan berpotensi untuk stimulan dalam produksi inokulum mikoriza arbuskula berupa spora dan kolonisasi akar yaitu cuka kayu karet, cuka akar pakis, dan cuka gambut.

\section{SARAN}

Jika akan memproduksi inokulum mikoriza arbuskula berupa spora dan kolonisasi akar yang banyak dapat menggunakan cuka kayu karet dan cuka akar pakis sebagai stimulan.Perlu dilakukan penelitian lebih lanjut terkait dengan pemberian konsentrasi cuka organik sebagai stimulan dalam menghasilkan produk inokulum mikoriza arbuskula terbaik berupa spora dan akar yang terinfeksi FMA.

\section{UCAPAN TERIMA KASIH}

Terima kasih kepada SEAMEO BIOTROP melalui Dr. Hanna Artuti Ekamawanti (sebagai Ketua Peneliti) telah membantu dana penelitian ini dari DIPA Biotrop 2017 yang berjudul "Pengembangan Sistem Paludikultur untuk Lahan Gambut Terdegradasi: Krakteristik Lahan Gambut dan Teknik Propagasi Tumbuhan Indigenos". 


\section{DAFTAR PUSTAKA}

[Anonim]. 2010. Cuka Kayu. Kelompok Kimia Pertanian, Knator Penelitian dan Pengembangan Ilmu Produksi Pertanian. Departemen Pertanian. Thailand.

Apai W, Thongdeethae S. 2001. Cuka kayu: Organik baru untuk Pertanian Thailand. 4th Toksisitas Divisi Conference. Departemen Pertanian.

Bhadalung NN, Suwanarit A, Dell B, Nopamornbodi O, Thamchaipenet A, Rungchuang J. 2005. Effects of Long-term NP-fertilization On Abundance and Diversity of Arbuscular Mycorrhyzal Fungi Under a Maize Cropping System. Plant and Soil 270(1-2):371-382.

Brundrett M. 2004. Diversity and Classification of Mycorrhizal Associations. Biol. Rev. 79:437495.

Brundrett MCL, Melville, Peterson L. 1994. Practical Methods in Mycorrhizal Research. Mycologie Publications, Ontario, Canada.

Brundrett MN, Bougher B, Dell T, Grove. Malajczuk N. 1996. Working With Mycorrhizas in Forestry and Agriculture. ACIAR Monograph. Canberra.

Chalimah S, Muhadiono, Aznam L, Haran S, TM Nurita. 2007. Perbanyakan Gigaspora sp dan Acaulospora sp dengan Kultur Pot di Rumah Kaca. Institut Pertanian Bogor. Bogor.

Delvian. 2006. Koleksi Isolat Cendawan Mikoriza Arrbuskula. USU Repositary. Medan.
Gunawan AW. 1993. Mikoriza Arbuskula. Edisi Pertama. Departemen Kehutanan. Jakarta.

Hardjowigeno S, Abdullah. 1987. Suitability of Peat Soils of Sumatera for Agricultural Development. International Peat Society. Symposium on Tropical Peat and Peatland for development. Yogyakarta, 9-14 Februari 1987.

Hermawan H, Muin A, Wulandari RS. 2015. Kelimpahan Fungi Mikoriza Arbuskula (FMA) Pada Tegakan Ekaliptus(Eucalyptus pelita) Berdasarkan Tingkat Kedalaman Di Lahan Gambut. Jurnal Hutan Lestari 3(1).

Husna, Tuheteru FD, Wigati E. 2017. Growth Response and Dependency of Endangered Nedun Tree Species (Pericopsis mooniana) Affected by Indegenous Arbuscular Mycorryzal Fungi Inoculation. Nusantara Bioscience. 9: 57 - 61.

Komarayati S, Susanto E. 2011. Arang dan Cuka Kayu produk HHBK untuk pertumbuhan stimulan mengkudu (Morinda citrifolia). Jurnal Penelitian Hasil Hutan. 29(2): 156.

Muin A. 2007. Pengaruh Cendawan Mikoriza Arbuskula (CMA) dan Intensitas Cahaya Terhadap Pertumbuhan Ramin (Gonystylus bancanus (Miq.) Kurz) di Persemaian. Penelitian Hutan Tanaman. 4(2) : $69-78$.

Rustamaji interview. 2018. Interview Tentang Cuka Organik. Rasau Jaya. 
Sadakichi, Kishimoto, Tsuyoshi H, Gould H. 2009. How to Improve Crop Quality While Reducing Dependence on Agricultural Chemicals. Wood Vinegar and Biochar in Agriculture. Jepang.

Sasli I, Ruliansyah A. 2012. Pemanfaatan Mikoriza Arbuskula Spesifik Lokasi untuk Efisiensi Pemupukan pada Tanaman Jagung di Lahan Gambut Tropis. Jurnal Agrovigor 5 (2):12

Satriadi T, Jauhari A, Ariandi M. 2010. Perbandingan Rendemen Cuka Kayu (Wood Vinegar) Jelutung (Dyera spp.) Berdasarkan Ukuran Bahan Baku. Jurnal Hutan Tropis 11(30): 47-55.

Schenck N, Perez Y. 1990. Manual for the Identification of VA Mycorrhizal fungi. Synergistis Publication. Gainesville. USA.

Schenck NC, Schroder VN. 1974. Temperature Response of
Endogone Mycorrhiza on Soybean Roots. Mycologia. 66: $600-605$.

Simanungkalit RDM. 2003. Teknologi Cendawan Mikoriza Arbuskuler: Produksi Inokulum dan Pengawasan Mutunya. Balai Penelitian Bioteknologi dan Sumberdaya Genetik Pertanian. Prosiding Seminar Mikoriza. Asosiasi Mikoriza Indonesia dan Universitas Padjajaran. Bandung.

Smith SE, Read DJ. 1997. Mycorrhizal symbiosis. Second edition. Academic Press. Harcourt Brace \& Company Publisher. London.

Smith SE, Read DJ. 2008. Mycorryzal Symbiosis. Academic Press. London (GB).

Suhardi. 1989. Pedoman Kuliah Mikoriza Vesikular Arbuskular (MVA). Universitas Gajah Mada. Yogyakarta. 